\title{
Do quality of services and institutional image impact students' satisfaction and loyalty in higher education?
}

\begin{abstract}
The objective of this study is to investigate whether the quality of educational services and the university's institutional image influence students' overall satisfaction with their university experience as well as the possible consequences of these relationships on students' loyalty. In particular, in today's increasingly competitive higher education environment, such concepts have become of strategic concern in both public and private universities. To explain the complex system of relationships among these constructs, several hypotheses were formulated and tested through a structural equation model (SEM). Data were collected through a web questionnaire handed out to 14,870 students enrolled at the University of Pisa. The results provide valuable insight and show that teaching and lectures and teaching and course organization are the main determinants of students' satisfaction and students' loyalty among the more academic components of the educational service. Furthermore, the crucial role played by university image is worth noting, both for its direct and indirect effects on students' satisfaction as well as on students' loyalty and on teaching and lectures.
\end{abstract}

Keywords Quality of educational services $\bullet$ Students' satisfaction • University image • Structural equation model $\bullet$ Latent variables

\section{Introduction}

Over the last 15 years, the Italian university system has undergone major changes, characterized by two reforms that have progressively modified the organizational and educational structure and by an increasing level of financial autonomy, which requires universities to be accountable for the public funds received. Furthermore, the reduction of public funding and its allocation at least to a certain extent based on performance criteria also require a more accurate assessment of effectiveness and efficiency in the utilization of resources. Following these changes in public policy, universities have become more student-oriented and engaged in a growing competition with each other. As a result, institutions have adopted market-oriented principles (DeShields et al. 2005), with the aim of gaining a competitive edge (Hemsley-Brown and Oplatka 2006), and higher education is viewed as a 'pure' service (Oldfield and Baron 2000), with students as their 'primary customers' (Douglas et al. 2006), since they are the direct recipients of educational services and are required to pay tuition fees. As a consequence, universities are interested in evaluating the students' educational experience and the level of satisfaction with the quality of services (Thomas and Galambos 2004).

Furthermore, since students make rational choices regarding degree courses and institutions (Baldwin and James 2000), universities are also concerned with understanding the factors driving students' choice of venue as to where to enrol (Foskett and HemsleyBrown 2001; Sojki et al. 2012). 
Therefore, from this point of view, institutional image and reputation are considered valuable assets for attracting prospective students as well as for competing with other universities' (Alves and Raposo 2007).

The aim of this study is to investigate whether the perceived quality of educational services and university image influence students' overall satisfaction with their university experience as well as the possible consequences of these relationships on students' loyalty. In particular, the research focuses on the possible effects on overall satisfaction by evaluating students' perceptions on a set number of typical educational services, such as teaching and lectures, teaching and course organization, educational infrastructure, student services offices and libraries and refectories. Moreover, this study investigates whether, among these services, teaching and lectures assume a prominent role by acting as mediators regarding students' satisfaction, since teaching activities are essential in characterizing the higher education experience and permanence in the university system. From this perspective, the particular attention given to the analysis of the relationships between university image, teaching and lectures and students' satisfaction constitutes a distinguishing feature of this study compared to others that have addressed the same issues in the literature of service quality in higher education.

For these purposes, several hypotheses were formulated and tested through a structural equation model (SEM). In particular, SEM was preferred over regression analysis because of its great modeling flexibility in terms of analyzing dependencies between endogenous and exogenous variables and in testing complex relationships or mediation hypotheses in a single analysis through a system of equations.

The paper is organised as it follows. Section 2 introduces data collection and measurement of variables. Section 3 presents the development of hypotheses. Section 4 describes the SEM with categorical variables. Section 5 shows the results after the estimation of the model, and finally, Section 6 is devoted to our discussion.

\section{Data collection and measurement of variables}

Data were collected through a web questionnaire handed out to a sample of 14,870 students enrolled at the University of Pisa in 2014. The entire population of students enrolled in the 2013-2014 academic year was 51,758, The survey was carried out with the purpose of acquiring useful information for drawing up a social report and making the results available to its community (students and their families, inhabitants, firms, municipality, the county etc.). The sample size was originally 16,277 of which 2,296 freshmen. The total number of students enrolled in the Bachelor's or single-cycle degree courses was 10,442, of which $16.7 \%$ coming from Humanities, $24.9 \%$ from Social Sciences, $40.1 \%$ from Scientific areas and $18.2 \%$ from Medical Sciences.

The survey questionnaire includes several sections concerning assessment of the quality of educational services (teaching and organizational activities, infrastructures and facilities, student services offices, libraries, job placement, counselling, refectories), perceived image of the university, opinion of overall university experience and students' loyalty. Each section of the questionnaire included a set number of items formulated to measure the students' perception regarding the above-mentioned aspects. The survey data were also matched with the administrative archives of the University of Pisa, where information on students' main characteristics and university careers are recorded.

\subsection{Definitions and Measurements of Variables}

Defining the concept of 'quality' in higher education is quite complex, given its multifaceted nature and the possibility of referring either to 'processes' or 'outcomes' (Harvey and Green, 1993; Srikanthan and Dalrymple 2003). Hence, its measurement first requires the theoretical definition of underlying dimensions or latent constructs and the use of 
appropriate instruments such as valid questionnaire items in order to assign the appropriate weights to each dimension.

In this paper, service quality was defined in terms of perception regarding outcomes, following the SERVPERF approach (Cronin and Taylor 1992) (see, for example, Abdullah 2006). More specifically, quality of educational services was assessed in terms of outcomes by measuring students' perception of and satisfaction with a number of academic and nonacademic activities on a four-ordered-categories-anchored scale $(1=$ 'none', 2 = 'a little', 3 $=$ 'enough' and $4=$ 'very much'). The rating assigned is considered an indicator of an underlying latent variable, whose value is expressed on a continuous scale that is observable only with a categorical response variable. In particular, the following five main dimensions were considered to represent the multidimensional nature of service quality, drawing from the existing literature: Teaching and lectures, Teaching and course organization, Educational infrastructure, Refectories and Student services offices.

Moreover, the constructs of University image, Students' satisfaction and University loyalty were also introduced to make the system of relationships more extensive and comprehensive. Finally, certain academic and extra-academic variables were also included in the model to describe students' characteristics.

A more detailed description of the constructs and the items employed for their measurement is provided.

\subsubsection{Teaching and Lectures}

Teaching and lectures are essential for characterizing the most typical academic component of service quality in higher education institutions. Teaching staff is considered to be the main actor in university activities (Harvey 1995; Pozo-Munoz et al. 2000). Hence, competence, behaviours, attitudes and teaching style of lecturers (Harvey, 1995) are essential for providing high-quality education (Douglas et al. 2006; Petruzzellis et al. 2006) and for defining students' perceptions of service quality in higher education (Voss et al. 2007). Based on the previous literature, the measurement of perceived quality of Teaching and lectures includes the following three indicators: highly qualified teachers $\left(\mathrm{y}_{1}\right)$, quality of the teaching activity $\left(\mathrm{y}_{2}\right)$ and quality of research $\left(\mathrm{y}_{3}\right)$. Specifically, quality of research has been considered, even though it is not immediately related to lectures, since it may be useful for indirectly qualifying the competence and skills of lecturers.

\subsubsection{Teaching and course organization}

To represent the instrumental and support activities needed for the effective delivery of lectures, Teaching and course organization is introduced as a separate dimension of service quality. In particular, the higher education literature identifies institutional performance and programme outcomes (Hartman and Schmidt 1995), efficiency of the teaching organization (Bini and Masserini 2016) and course organization and assessment (Harvey 1995) as important factors for profitable student experiences. Hence, the measurement of Teaching and course organization defines an extensive concept and includes four items: organization of exams (appeals, information, bookings) $\left(\mathrm{y}_{4}\right)$, class schedule $\left(\mathrm{y}_{5}\right)$, support provided by non-academic personnel $\left(\mathrm{y}_{6}\right)$ and online services $\left(\mathrm{y}_{7}\right)$. Such items have the aim of characterizing the efficiency of the organization in teaching activities and related services.

\subsubsection{Educational Infrastructure}

It is commonly understood, and confirmation is found in the literature, that the physical environment, layout, lighting, classrooms, appearance, cleanliness and overall conditions of buildings significantly contribute to students' concept of service quality in higher education (Douglas et al. 2006). Accordingly, Educational infrastructure is introduced as a separate dimension to take more tangible aspects into account in the process of educational service delivery. Hence, the measurement of the following four items was employed to characterize the physical settings where teaching activities take place: lecture halls $\left(\mathrm{y}_{8}\right)$, laboratories $\left(\mathrm{y}_{9}\right)$, cleanliness $\left(\mathrm{y}_{10}\right)$ and meeting places $\left(\mathrm{y}_{11}\right)$. 
2.1.4 Quality of other educational services: Libraries, refectories and student services offices

Living in the university system is also characterized by the fruition of a number of auxiliary educational services, such as administrative services, libraries, computer and laboratory facilities, refectories and student accommodations, among others. Research studies show that support facilities for teaching and learning can help universities meet students' expectations and maintain service quality in higher education (Harvey 2003; Ilias et al. 2008). For the purposes of this study, libraries, refectories and student services offices were introduced as separate dimensions, and the measurement of these facilities includes the following items, respectively: for Libraries - number of seats $\left(\mathrm{y}_{12}\right)$, opening hours $\left(\mathrm{y}_{13}\right)$, number and variety of journals/databases $\left(\mathrm{y}_{14}\right)$ and availability of textbooks $\left(\mathrm{y}_{15}\right)$; for Refectories - quality of food $\left(\mathrm{y}_{16}\right)$, variety of menu $\left(\mathrm{y}_{17}\right)$ and cleaning $\left(\mathrm{y}_{18}\right)$; and for Student services offices - information on administrative procedures and practices $\left(\mathrm{y}_{19}\right)$, online services $\left(\mathrm{y}_{20}\right)$, response times to email requests $\left(\mathrm{y}_{21}\right)$, relationship with the staff $\left(\mathrm{y}_{22}\right)$ and support provided by staff $\left(\mathrm{y}_{23}\right)$.

\subsubsection{University Image}

In the higher education literature, perceived image has been defined as all of the sensations and impressions one individual feels towards the university (Arpan et al. 2003; Landrum et al. 1998) and can be influenced by tangible and intangible organizational elements, communication and personal and social values. Many factors can contribute to the characterization of university image, such as infrastructure, personal relationships, environmental factors, academic features, teaching and research, quality of education, academic practices and facilities and employment opportunities, among others (Aghaza et al. 2015; Arpan et al. 2003; Duarte et al. 2010). In this study, focusing on the concept of image as beliefs based on intangible elements, the measurement of University image refers to the students' perception of the institution expressed in terms of the following aspects: prestigious $\left(\mathrm{y}_{24}\right)$, modern $\left(\mathrm{y}_{25}\right)$, famous $\left(\mathrm{y}_{26}\right)$ and in contact with the labour market $\left(\mathrm{y}_{27}\right)$. In particular, here the term modern means that the university has degree programmes continuously updated, in step with the evolution of technology and scientific progress, and it is open to international cultural exchanges.

\subsubsection{Students' Satisfaction}

Students' satisfaction with their overall university experience is a debated topic in the higher education literature (see, among others, DeShields et al. 2005; Elliott and Healy 2001; Elliott and Shin 2002; Marzo-Navarro et al. 2005). Given this, for the purposes of this study, 'university experience' refers to the overall academic experience and defines an extensive dimension of satisfaction regarding students' evaluation of their relationships with teachers and classes as well as with other aspects of university life, such as administrative practices and staff, infrastructure, social environment, student lifestyle, extracurricular activities and counselling support and mentoring (see, for example, DeShields et al. 2005; Thomas and Galambos 2004). The measurement of Students' satisfaction includes the subjective evaluation of the following three items: satisfaction with the choice of enrolling at the University of Pisa ( $\left.\mathrm{y}_{28}\right)$, satisfaction compared to initial expectations ( $\left.\mathrm{y}_{29}\right)$ and overall satisfaction $\left(\mathrm{y}_{30}\right)$.

\subsubsection{Students' Loyalty}

In higher education, student loyalty has been defined as the intention to advise one's friends and acquaintances to enrol in the same university one attended, the wish to speak positively about the institution and the will to return in the future to undertake further studies (Webb and Jagun 1997). An additional definition refers to student willingness to say positive things about the institution and to inform new candidates about the university. According to Henning-Thurau et al. (2001), loyal students may decide to support their academic institution both financially and through positive 'word-of-mouth'. Hence, the measurement of Students' loyalty is designed to summarize the previous aspects by using the following 
two items: intention to enrol again at the University of Pisa $\left(\mathrm{y}_{31}\right)$ and intention to recommend the University of Pisa to a relative, a friend or an acquaintance $\left(\mathrm{y}_{32}\right)$.

\section{Development of hypotheses}

The proposed theoretical model is developed after a thorough review of the literature on service quality in higher education, whose findings were combined with our personal reflections and represented by a set of hypotheses.

The analysis of the literature reveals that students' perception of an academic institution's quality is an antecedent of their overall satisfaction (Guolla 1999). In particular, a positive perception of both service quality (Alves and Raposo, 2010) and the quality of campus services (Gibson 2010), including participation in campus recreational sports (Lindsey 2012) and the development of social services (Arslan and Altinbas-Akkas 2014), are related to students' satisfaction. As a consequence, universities are required to achieve high standards of quality in teaching, research, support and administrative services in order to better pursue their mission and stay competitive. Furthermore, another strand of research studies suggests that factors beyond perceived value and perceived quality into account, such as institutional image and the reputation of the university, are possible predictors of students' satisfaction (Alves and Raposo 2007; Arslan and Altinbas-Akkas 2014; Brown and Mazzarol 2009; Duarte et al. 2010; Gibson 2010; Gruber et al. 2010; Guolla 1999; Lindsey 2012). More specifically, perceived institutional image has now become one of the main determinants for choosing where to enrol and can be effective for attracting the best students and teachers (Arpan et al., 2003; Duarte et al., 2010), since it is often regarded as even more important than infrastructure, quality and other specific characteristics (Hashim et al. 2015). Additional studies show that institutional image and reputation, perceived value, perceived quality and student satisfaction are also key antecedents for student loyalty (Alves and Raposo 2010; Brown and Mazzarol 2009; Eskildsen et al. 1999; Tarus and Rabach 2013), whereas other findings show that perceived service quality and student satisfaction can lead to student loyalty only indirectly via trust and commitment (RojasMendez et al., 2009). Finally, students' satisfaction and loyalty may result in positive wordof-mouth communication (Alves and Raposo 2010; Poturak 2014) in the form of face-toface or online opinions from alumni and actual students.

The whole system of hypotheses which constitute the theoretical model to be verified is described in more detail in the following subsections. First, it is shown that in academic institutions, students' perceptions of service quality and university image are antecedents of overall satisfaction. Afterwards, University image and Students' satisfaction are also evaluated as potential antecedents of Students' loyalty. Finally, the prominent role of Teaching and lectures as a possible mediator between Students' satisfaction, University image and the other instrumental services is described.

\subsection{The Influence of Quality of Educational Services on Students' Satisfaction}

The complex system of hypotheses was built by recognizing that everything that surrounds teaching is essential in characterizing the relationship between students and a given university. Research studies have found that teaching quality (Alves and Raposo 2007; Douglas et al. 2006; Mergen et al. 2000; Petruzzellis et al. 2006; Voss et al., 2007), quality of instruction (DeBourgh 2003) and instructor teaching style (Dana et al. 2001) are key determinants of students' satisfaction. Moreover, the organizational aspect and functioning of universities, such as characteristics of university departments (Umbach and Porter 2002), institutional performance and programme outcomes (Hartman and Schmidt 1995), administrative support (Grunwald and Peterson 2003) and efficiency of the teaching organization (Bini and Masserini 2016), all have positive effects on students' satisfaction 
and that having appropriate infrastructure, academic buildings and recreation places may also foster satisfaction (Gruber et al. 2010; Harvey 2003; Ilias et al. 2008; Sapri et al. 2009). Finally, during their experience in the university system, students benefit from a number of auxiliary educational facilities, such as student services offices, refectories and libraries, although less frequently than other academic services. These support facilities can affect students' satisfaction (Harvey, 2003; Ilias et al. 2008).

Based on the previous literature, several hypotheses that define the positive influence of the following dimensions on students' satisfaction can be derived: Teaching and lectures $\left(\mathrm{H}_{1}\right)$, Teaching and course organization $\left(\mathrm{H}_{2}\right)$, Educational infrastructure for teaching activities $\left(\mathrm{H}_{3}\right)$, satisfaction with Libraries $\left(\mathrm{H}_{4}\right)$, satisfaction with Refectories $\left(\mathrm{H}_{5}\right)$ and satisfaction with Student services offices $\left(\mathrm{H}_{6}\right)$.

Moreover, in order to explain differences in students' satisfaction and obtain more accurate inferences, the status of freshmen, the type of course and gender were also included in the model as control variables: gender $\left(\mathrm{H}_{7}\right)$, freshmen status $\left(\mathrm{H}_{8}\right)$ and type of course (first-level vs second-level degree courses) $\left(\mathrm{H}_{9}\right)$.

\subsection{The Influence of University Image on Students' Satisfaction and Students' Loyalty}

The relationship between university image and satisfaction appears to be somewhat controversial in the literature (Alves and Raposo 2010). Indeed, several studies suggest that university image directly influences students' satisfaction (Alves and Raposo 2010; Brown and Mazzarol 2009; Eskildsen et al. 1999; Palacio et al. 2002), and other studies assert that satisfaction is an antecedent of students' perception of the university's image (Helgesen and Nesset 2007). Finally, some studies even say that no relationship exists between corporate image and satisfaction. However, this study supports the hypothesis that University image is positively related to Students' satisfaction $\left(\mathrm{H}_{10}\right)$, since it is reasonable to retain that those who believe they are in a qualified and challenging environment are also more likely to be satisfied with their own educational experience, other things held constant.

Moreover, a considerable part of the literature highlights the notion that university image and student satisfaction are both possible antecedents of students' loyalty (Alves and Raposo 2007; Brown and Mazzarol 2009; Nguyen and LeBlanc 2001; Tarus and Rabach 2013). In particular, according to Eskildsen et al. (1999), university image constitutes the construct with the greatest influence on students' loyalty. Hence, two hypotheses define the positive influence on Students' loyalty through the following constructs, respectively: University image $\left(\mathrm{H}_{11}\right)$ and Students' satisfaction $\left(\mathrm{H}_{12}\right)$.

\subsection{The Role of Teaching and Lectures}

To strengthen the importance of teaching for the university experience as the most significant and typical academic component of service quality in higher education, the construct of Teaching and lectures is expected to play the role of mediator between Students' satisfaction and other instrumental educational services, such as Teaching and course organization, Educational infrastructure and Student services offices. According to this point of view, a more profitable learning experience may also be guaranteed by a positive assessment of services instrumental to lectures. As a consequence, three hypotheses describe the positive influence on Teaching and lectures from the following constructs: Teaching and course organization $\left(\mathrm{H}_{13}\right)$, Educational infrastructure $\left(\mathrm{H}_{14}\right)$ and Student services offices $\left(\mathrm{H}_{15}\right)$.

Moreover, given the relationship between teaching quality and university image drawn from the existing literature (Duarte et al. 2010; Palacio et al. 2002), and taking into account the influence of image on students' satisfaction and loyalty, a further hypothesis describes the positive influence of University image on Teaching and lectures $\left(\mathrm{H}_{16}\right)$. In particular, this hypothesis states that the perception of being in a prestigious, modern and famous university can lead to a more favourable assessment of one's experience of teaching and learning, and this may happen independently from the actual service delivery.

The path diagram in Figure 1 gives a pictorial representation of the hypothesized system of relationships among constructs. Rectangular boxes represent observed explanatory 
variable, circles represent endogenous or exogenous latent variables and arrows indicate directional relationships, such as regression coefficients between the corresponding observed or latent variables.

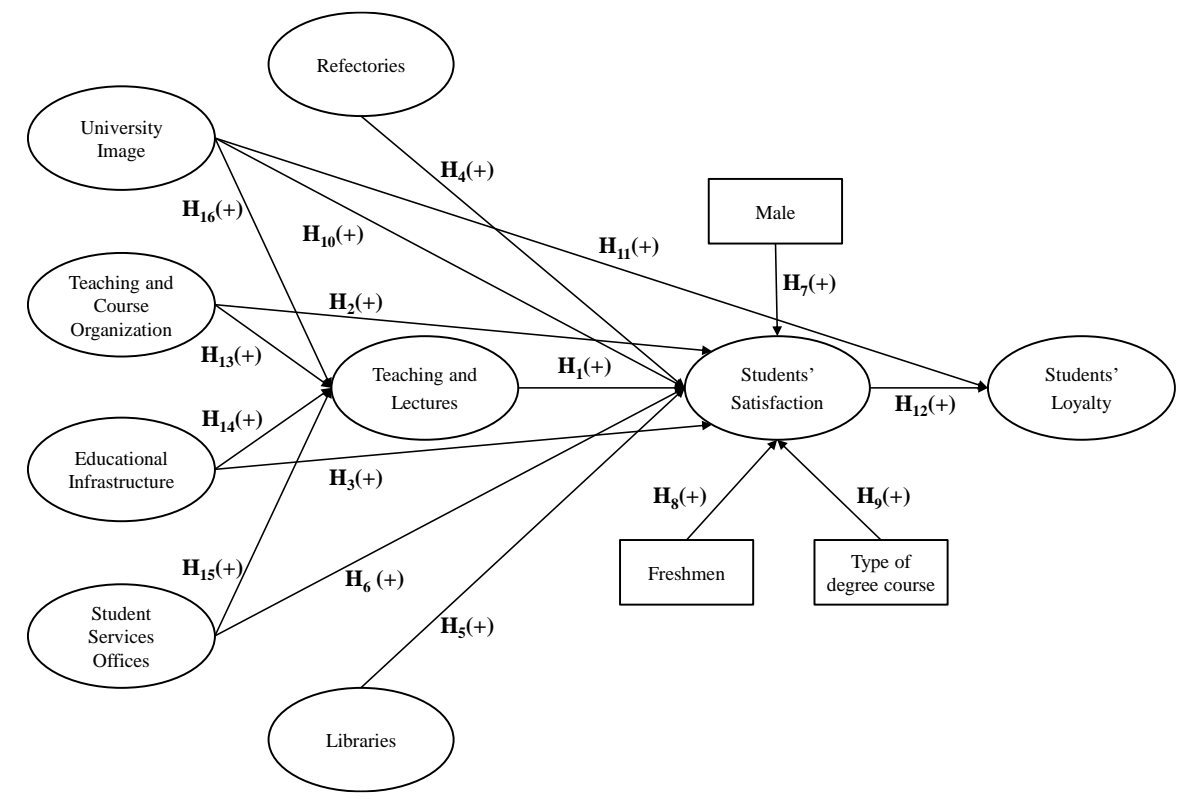

Fig. 1. Path diagram of the hypothesized model

\section{Structural equation models with categorical variables}

Structural equation models comprise a family of multivariate statistical methods that allow researchers to test a theoretical model specified in terms of a complex system of relationships among variables (exogenous and endogenous), observed or latent, through a system of equations. An SEM model is characterized by two components: a measurement model and a structural model (Bollen 1989). The measurement model defines the relationships between the observed responses or indicators and the latent variables through a confirmatory factor model (Jöreskog 1969). The structural model specifies the dependencies among latent variables and regressions among latent and observed variables. With ordinal observed indicators for the latent variables, typically arising from the responses to a questionnaire consisting of $\mathrm{p}$ Likert-type scale items, denoted with $\mathrm{y}_{j}$, where $j$ $=1, \ldots, p$, the measurement model can be specified (as in Muthén 1984) through continuous and normally distributed latent variables, indicated with $y_{j}^{*}$, underlying each observed variable. In particular, the observed responses are assumed to result from the categorization of the latent response (Bandalos 2014) into a number of ordered categories, defined by threshold values, so that latent responses and observed indicators are linked via threshold models, and thus yield ordered polytomous probit measurement models. Hence, given the jth observed variable with $K$ mutually exclusive and ordered response categories, indicated by $k=0,1,2, \ldots, K-1$, the underlying latent variable is defined by a set of threshold parameters, $\tau_{\mathrm{j}, \mathrm{k}}$, as follows:

$$
y_{j}=k \text { if } \tau_{j, k}<y_{j}^{*}<\tau_{j, k+1}
$$


where $\tau_{\mathrm{j}, 0}=-\infty$ and $\tau_{\mathrm{j}, \mathrm{k}-1}=+\infty$. That is, based on the threshold model, alternative $k$ for item $j$ is chosen by an individual when the corresponding latent response value $y_{j}^{*}$ is between thresholds $\tau_{\mathrm{j}, \mathrm{k}}$ and $\tau_{\mathrm{j}, \mathrm{k}+1}$ (Forero et al. 2009). Moreover, the measurement model also assumes that the factors are related to the vector of latent responses $\mathbf{y}^{*}$ by means of an ordinal factor analytic model:

$$
\mathbf{y}^{*}=\Lambda \boldsymbol{\eta}+\boldsymbol{\varepsilon}
$$

where $\mathbf{y}^{*}$ is a $p \times 1$ vector of latent responses; $\Lambda$ is a $p \times m$ matrix of factor loadings; $\boldsymbol{\eta}$ is an $m \times 1$ vector of latent factors underlying the observed indicators and $\varepsilon$ is a $p \times 1$ vector of residuals. Both latent factors and residuals are assumed normally distributed with mean of zero, and are uncorrelated with each other. Under these assumptions, the latent responses $y_{j}^{*}$ are normally distributed with mean zero and covariance matrix:

$$
\boldsymbol{\Sigma}=\boldsymbol{\Lambda} \boldsymbol{\Psi} \Lambda^{\prime}+\boldsymbol{\Theta}
$$

Here, $\boldsymbol{\Psi}$ and $\boldsymbol{\Theta}$ are the factors and measurement errors covariance matrices, respectively; generally, it is further assumed that measurement errors are mutually uncorrelated, so that $\Theta$ is diagonal, even though some correlated errors are also possible. The ordinal factor model is identified by setting $\boldsymbol{\Theta}=\mathbf{I}-\operatorname{diag}\left(\boldsymbol{\Lambda} \boldsymbol{\Psi} \mathbf{\Lambda}^{\prime}\right)$, in addition to the general identification rules of the standard factor model (see, e.g. Bollen 1989). Moreover, given the restriction imposed on the elements of $\boldsymbol{\Theta}$, the covariance matrix of the latent responses $y_{j}^{*}, \Sigma$, is a matrix of polychoric correlations, $\boldsymbol{\rho}$, which returns the estimates of the linear relationship between two unobserved continuous and normally distributed variables.

The structural model can be expressed by the following equation (Muthén 1984):

$$
\boldsymbol{\eta}=\boldsymbol{\beta} \boldsymbol{\eta}+\boldsymbol{\Gamma} \mathbf{x}+\zeta
$$

where $\boldsymbol{\eta}$ is an $m \times 1$ vector of endogenous latent variables; $\boldsymbol{\beta}$ is an $m \times m$ matrix for endogenous latent variables; $\Gamma$ is an $m \times k$ matrix of regression coefficients among latent and observed variables; $\mathbf{x}$ is a $k \times 1$ vector of exogenous observed variables and $\zeta$ is an $m \times$ 1 vector of errors.

The model parameters, summarized in vector $\boldsymbol{\theta}=(\boldsymbol{\tau}, \boldsymbol{\rho}, \mathbf{B}, \boldsymbol{\Gamma}, \boldsymbol{\Lambda}, \boldsymbol{\Psi}, \boldsymbol{\Theta})$, can be estimated with a three-stage, limited-information procedure, as described in Muthén (1984) and Muthén and Satorra (1995), by using a weighted least-squares fit function. In the first stage, first-order statistics (thresholds) are consistently estimated for each variable at a time by maximum-likelihood (ML). In the second stage, second-order statistics (polychoric correlations) are consistently estimated from each pair of variables by conditional ML, that is, for given first-stage estimates. The parameters obtained in the first two stages of the procedure (thresholds and polychoric correlations) are then summarized in a vector, denoted by $\mathbf{s}=(\tau, \boldsymbol{\rho})$, and parameters of the structural model are thus estimated by minimizing the following least square function:

$$
F=(\mathbf{s}-\boldsymbol{\sigma}(\boldsymbol{\theta}))^{\prime} \mathbf{W}^{-1}(\mathbf{s}-\boldsymbol{\sigma}(\boldsymbol{\theta}))
$$

Here, $\boldsymbol{\sigma}(\boldsymbol{\theta})$ contains the model-implied thresholds and polychoric correlations, whereas $\mathbf{W}$ is an appropriate positive-definite weight matrix. Specifically, a crucial aspect in this step is the choice of the weight matrix. If it contains the elements of the asymptotic covariance matrix of first- and second-order statistics computed in the first two stages, given by the vector of the first derivatives of thresholds and polychoric correlations, the weighted least squares (WLS) estimator is obtained (Muthén 1984; Muthén and Satorra 1995); instead, if it 
contains only the diagonal elements of the asymptotic covariance matrix, consisting of the asymptotic variances of thresholds and polychoric correlations, as suggested by Muthèn, du Toit and Spisic (1997), a diagonally weighted-least squares (DWLS) estimation is obtained. More specifically, a beneficial feature of this second approach is that $\mathbf{W}$ need not be inverted, which can be problematic for models containing a large number of variables and/or small samples. Furthermore, this methodology is 'very computationally efficient, reducing a possibly high dimensional integration problem to a series of univariate and bivariate integrations, which is especially valuable for models with many latent variables' (Skrondal and Rabe-Hesketh 2004).

\section{Results}

The research hypotheses described in Section 3 were verified by a structural equation model, carried out with the software Mplus 7.31 (Muthén and Muthén 1998-2010). First, confirmatory factor analysis (CFA) was applied to examine the validity and reliability of the measurements through the assessment of the internal structure of the model (Bagozzi and Yi 1988) in order to verify how hypothetical constructs were measured in terms of the observed indicators (subsection 4.1). Then, the relationships among the analysed constructs were tested with the structural model, after which the results will be discussed (subsection 4.2). The overall goodness-of-fit of the proposed model was evaluated on the basis of the criteria suggested by Bagozzi and Yi (1988), such as the model chi-square, the Comparative Fit Index (CFI), the Tucker-Lewis Index (TLI), the Standardized Root Mean Square Residual (SRMR) and the Root-Mean-Square Error of Approximation (RMSEA), whereas cut-off values $^{1}$ for acceptable fit were assessed by referring to $\mathrm{Hu}$ and Bentler (1999). However, since the model chi-square is sensitive to sample size and to slight model misspecifications, thus suggesting that there will almost always be an inadequate fit between the hypothesized model and sampled data, more attention was given to the other fit indices. The results are shown in Table 1 and Figure $2^{2}$, respectively.

\subsection{Measurement Model}

The results of confirmatory factor analysis are shown in Table 1 and reveal an excellent model fit in a variety of goodness-of-fit indices, except for the model chi-square, as predicted given the sample size: chi-square $=13,193.161(\mathrm{df}=428 ; \mathrm{p}<0.001)$; CFI $=$ 0.977 ; TLI $=0.974 ;$ RMSEA $=0.043$, with the $90 \%$ confidence interval $0.042-0.044$; and WRMSR $=4.254$. Moreover, further measures were used to assess the internal structure of the model: analysis of the values and significance of all estimated factor loadings, individual item reliability, latent variable Composite Reliability (CR) and Average Variance Extracted (AVE) of the latent variable (Bagozzi and Yi 1988). Nevertheless, it is worth noting that, as categorical rather than continuous indicators of latent variables were used, slightly lower values in some of the cut-offs are possible but may still be considered acceptable (Cronbach 1951).

As indicated in Table 1, all standardized factor loadings are significant ( $\mathrm{p}<0.001)$ and greater than 0.5 except one (class schedule - $\mathrm{y}_{5}$ - which is just below at 0.416 ), and this demonstrates that the identified indicators effectively measure their corresponding construct. More specifically, all the CRs are between 0.605 and 0.960 and meet the 0.60 criteria, whereas the AVEs are between 0.280 and 0.889 , even though four out of the nine

${ }^{1}$ In particular, "rules of thumb" conventional cutoff values were: at least 0.95 for both CFI and TLI and at least 0.90 as an acceptable fit; a value not exceeding 0.06 for RMSEA; a value less than 0.08 for SRMR; less than 0.90 for WRMR; and between less than 2 and 5 for the relative model chi-square.

${ }^{2}$ In the following, asterisks indicate parameters significantly different from zero at levels $\mathrm{p}$ $<0.05(*), \mathrm{p}<0.01(* *)$ and $\mathrm{p}<0.001(* * *)$, respectively. 
are below the cut-off of 0.50 . Furthermore, for each construct, the square root of AVE is greater than the correlation between the corresponding construct and the other constructs in the model, and this is indicative of discriminant validity. Therefore, despite a few minor exceptions, the findings suggest that, according to the criteria proposed by Bagozzi and Yi (1988), the measurement model exhibits both an excellent overall fit and a good internal structure. The model thus demonstrates adequate reliability and convergent validity of measurements in addition to acceptable discriminant validity between the constructs.

Tab. 1. Measurement model estimates

\begin{tabular}{|c|c|c|c|c|}
\hline Constructs and Indicators & $\begin{array}{l}\text { Standardized } \\
\text { Factor } \\
\text { Loading }\end{array}$ & $\begin{array}{l}\text { Individual } \\
\text { Item } \\
\text { Reliability }\end{array}$ & $\begin{array}{l}\text { Composite } \\
\text { Reliability }\end{array}$ & $\begin{array}{c}\text { Average } \\
\text { Variance } \\
\text { Extracted } \\
\text { (AVE) }\end{array}$ \\
\hline Teaching and Lectures & & & 0.827 & 0.616 \\
\hline highly qualified teachers $\left(\mathrm{y}_{1}\right)$ & $0.878 * * *$ & 0.771 & & \\
\hline quality of the teaching activity $\left(\mathrm{y}_{2}\right)$ & $0.713 * * *$ & 0.508 & & \\
\hline quality of research $\left(\mathrm{y}_{3}\right)$ & $0.754 * * *$ & 0.569 & & \\
\hline Teaching and Course Organization & & & 0.605 & 0.280 \\
\hline $\begin{array}{l}\text { organization of exams (appeals, information, } \\
\text { bookings) (y4) }\end{array}$ & $0.552 * * *$ & 0.305 & & \\
\hline class schedule (y5) & $0.416 * * *$ & 0.173 & & \\
\hline support provided by non-academic personnel $\left(\mathrm{y}_{6}\right)$ & $0.550 * * *$ & 0.303 & & \\
\hline online services $\left(\mathrm{y}_{7}\right)$ & $0.581 * * *$ & 0.338 & & \\
\hline Educational Infrastructure & & & 0.716 & 0.389 \\
\hline lecture halls $(\mathrm{y} 8)$ & $0.643 * * *$ & 0.413 & & \\
\hline laboratories ( $\left.\mathrm{y}_{9}\right)$ & $0.675 * * *$ & 0.456 & & \\
\hline cleanliness ( $\left.\mathrm{y}_{10}\right)$ & $0.537 * * *$ & 0.288 & & \\
\hline meeting places $\left(\mathrm{y}_{11}\right)$ & $0.630 * * *$ & 0.397 & & \\
\hline Libraries & & & 0.691 & 0.362 \\
\hline number of seats $\left(\mathrm{y}_{12}\right)$ & $0.540 * * *$ & 0.292 & & \\
\hline opening hours $\left(\mathrm{y}_{13}\right)$ & $0.524 * * *$ & 0.275 & & \\
\hline number and variety of journals/databases $\left(\mathrm{y}_{14}\right)$ & $0.637 * * *$ & 0.406 & & \\
\hline availability of textbooks $\left(\mathrm{y}_{15}\right)$ & $0.690 * * *$ & 0.476 & & \\
\hline Refectories & & & 0.761 & 0.515 \\
\hline quality of food (y16) & $0.744 * * *$ & 0.554 & & \\
\hline variety of menu $\left(\mathrm{y}_{17}\right)$ & $0.707 * * *$ & 0.500 & & \\
\hline cleaning $(\mathrm{y} 18)$ & $0.700 * * *$ & 0.490 & & \\
\hline Student Services Offices & & & 0.847 & 0.526 \\
\hline $\begin{array}{l}\text { information on administrative procedures and } \\
\text { practices }\left(\mathrm{y}_{19}\right)\end{array}$ & $0.729 * * *$ & 0.531 & & \\
\hline online services $\left(\mathrm{y}_{20}\right)$ & $0.700 * * *$ & 0.490 & & \\
\hline response times to email requests $\left(\mathrm{y}_{21}\right)$ & $0.709 * * *$ & 0.503 & & \\
\hline relationship with the staff $\left(\mathrm{y}_{22}\right)$ & $0.752 * * *$ & 0.566 & & \\
\hline support provided by staff $\left(\mathrm{y}_{23}\right)$ & $0.735 * * *$ & 0.540 & & \\
\hline University Image & & & 0.742 & 0.424 \\
\hline prestigious ( $\left.\mathrm{y}_{24}\right)$ & $0.697 * * *$ & 0.486 & & \\
\hline modern $\left(\mathrm{y}_{25}\right)$ & $0.501 * * *$ & 0.251 & & \\
\hline famous $\left(\mathrm{y}_{26}\right)$ & $0.756 * * *$ & 0.572 & & \\
\hline in contact with the labour market $\left(\mathrm{y}_{27}\right)$ & $0.623 * * *$ & 0.388 & & \\
\hline Students' Satisfaction & & & 0.960 & 0.889 \\
\hline $\begin{array}{l}\text { satisfaction with the choice of enrolling at the } \\
\left.\text { University of Pisa ( } \mathrm{y}_{28}\right)\end{array}$ & $0.950 * * *$ & 0.903 & & \\
\hline satisfaction compared to initial expectations (y29) & $0.896 * * *$ & 0.803 & & \\
\hline overall satisfaction $\left(\mathrm{y}_{30}\right)$ & $0.980 * * *$ & 0.960 & & \\
\hline Students' Loyalty & & & 0.938 & 0.883 \\
\hline $\begin{array}{l}\text { intention to enrol again at the University of Pisa } \\
\left(\mathrm{y}_{31}\right)\end{array}$ & $0.932 * * *$ & 0.869 & & \\
\hline $\begin{array}{l}\text { intention to recommend the University of Pisa to a } \\
\text { relative, a friend or an acquaintance }\left(\mathrm{y}_{32}\right)\end{array}$ & $0.947 * * *$ & 0.897 & & \\
\hline
\end{tabular}

relative, a friend or an acquaintance $\left(\mathrm{y}_{32}\right)$

0.897

$0.001(* * *)$, respectively. 


\subsection{Structural Model}

The relationships among the constructs were tested by the structural model according to the research hypotheses previously developed, and the empirical results after model estimation are shown in Figure 2. The measures of model fit indicate an excellent overall fit even for the structural model, except for the chi-square statistic, which, also in this case, is due to sample size: chi-square $=14,150.965(\mathrm{df}=526 ; \mathrm{p}<0.001) ; \mathrm{CFI}=0.974 ;$ TLI $=0.971$; RMSEA $=0.042$, with the $90 \%$ confidence interval 0.041-0.043; and WRMSR $=4.442$. As a further measure of model adequacy, the explained variance was examined and shows rather high values for each of the three endogenous latent variables, albeit with some differences: Students' satisfaction (0.477), Students' loyalty (0.802) and Teaching and lectures (0.795). Moreover, based on the inspection of the results, no negative error variances, correlations greater than one, extremely large parameter estimates, or nonsignificant error variances were observed. Therefore, overall, these measures are satisfactory and allow us to trust the system of relationships as well as the results of the model estimation. In the following subsections, to facilitate reading, relations among constructs are described separately depending on whether they refer to direct and indirect effects on Students' satisfaction, Students' loyalty and to the analysis of factors affecting Teaching and lectures, respectively.

\subsection{Analysis of Direct and Indirect Effects on Students' Satisfaction}

From the analysis of the path diagram and corresponding regression coefficients (Figure 2), most of the hypotheses formulated seem to be verified and have the expected sign, as indicated in Figure 1 In particular, among the educational services, the construct of Teaching and lectures has a positive and direct effect $(+0.258)$ on Students' satisfaction (supporting $\mathrm{H}_{1}$ ) as well as support and instrumental activities, here represented by Teaching and course organization $(+0.478)$ (supporting $\mathrm{H}_{2}$ ). Contrary to expectations, Student services offices has a weak but negative effect (-0.188) (not supporting $\mathrm{H}_{6}$ ), whereas Educational infrastructure has no direct effect (not supporting $\mathrm{H}_{3}$ ). However, Educational infrastructure has a small negative and indirect effect on Students' satisfaction through the mediation of Teaching and lectures $(-0.150 \times 0.258=-0.041)$, which therefore acts as full mediator of this relationship. Finally, with respect to the influence of the other instrumental services, a positive evaluation of Refectories only weakly affects Students' satisfaction (+0.098) (supporting $\mathrm{H}_{4}$ ), whereas there is no effect of Libraries (not supporting $\mathrm{H}_{5}$ ). Furthermore, the important role University image plays as a determinant of Students' satisfaction is worth noting: in fact, in addition to a small positive and direct effect $(+0.131)$ (supporting $\mathrm{H}_{10}$ ), a stronger influence is exercised through the mediation of Teaching and lectures $(+0.847 \times 0.258=0.476)$. As a consequence, summing the direct and indirect effects, it seems that the conditioning resulting from beliefs towards the institution contributes more than other factors to a satisfactory experience in the university system $(+0.136+0.476=0.612)^{1}$, even more than the effect exercised by Teaching and lectures $(+0.258)$ and Teaching and course organization $(+0.478+0.238 \times 0.258=0.539)$. Finally, the effects of some observed variables, such as gender, type of degree course and status of freshmen, were also introduced to further test the hypotheses and to avoid making improper inferences, thereby increasing the accuracy of the results. In this respect, neither gender nor type of degree course effects were observed (not supporting $\mathrm{H}_{7}$ and $\mathrm{H}_{9}$ ), whereas freshmen show a somewhat higher level of satisfaction than students enrolled in subsequent years (supporting $\mathrm{H}_{8}$ ).

\subsection{Analysis of Direct and Indirect Effects on Students' Loyalty}

The analysis of relationships involving Students' loyalty is described by only a few hypotheses. First of all, it is worthwhile to point out that Students' satisfaction is the

\footnotetext{
${ }^{1}$ In the case of one factor that is influenced directly and indirectly by another factor, the overall effect on such factor is given by the sum of the direct and indirect effects, where the indirect effect is computed by the product between the coefficients of the involved factors.
} 
construct which exercises the strongest influence on Students' loyalty (supporting $\mathrm{H}_{12}$ ) and shows a high direct and positive effect $(+0.806)$, as expected. Moreover, University image also has a direct and positive effect (supporting $\mathrm{H}_{11}$ ), although its influence is much lower (+0.131). Nevertheless, since University image is also related to Students' loyalty through the mediation of Students' satisfaction $(+0.136 \times 0.806=0.110)$, the total effect is even higher $(+0.136+0.110=0.246)$. Finally, a significant and positive but indirect effect on Students' loyalty is also exercised by the two most typical educational components, that is, Teaching and lectures $(+0.258 \times 0.806=0.208)$ and Teaching and course organization $(+0.478 \times 0.806=0.385)$.

\subsection{Analysis of the Factors Affecting Teaching and Lectures}

As stated by the hypotheses underlying the theoretical model, Teaching and lectures plays a double role, as an independent variable for Students' satisfaction and as a dependent variable as a function of instrumental and support activities as well as of University image. More specifically, when analysing Teaching and lectures as a dependent variable, the formulated hypotheses are verified only in part. Indeed, Teaching and course organization has a direct and positive influence $\left(+0.238\right.$ ) (supporting $\mathrm{H}_{13}$ ), whereas Educational infrastructure has a weak and negative effect (-0.150) (not supporting $\mathrm{H}_{14}$ ) as does Student services offices (-0.064) (not supporting $\mathrm{H}_{15}$ ). Instead, University image surprisingly appears to be the most influential variable, with a direct and positive effect $(+0.847)$ (supporting $\mathrm{H}_{16}$ ).

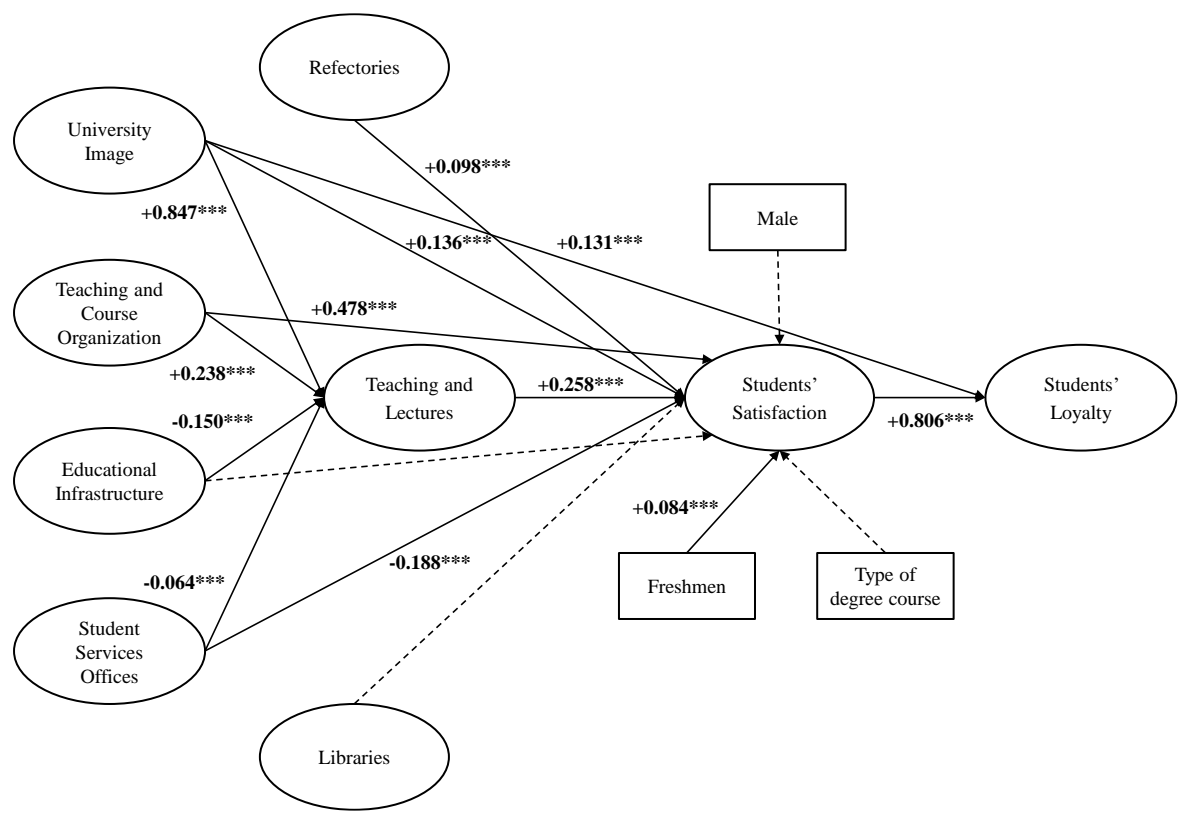

Fig. 2. Path diagram of the estimated model

\section{Discussion}

In a highly competitive higher education environment, in which universities aim to meet the expectations of their students, service quality constitutes an essential parameter of excellence, while concepts such as institutional image, students' satisfaction and loyalty have become of strategic concern in both public and private institutions. In this study, a structural equation model was carried out to test a theoretical model described through a set 
of underlying hypotheses, with the aim of explaining the relationship between perceived quality of the educational services, image and students' overall satisfaction with their university experience and to examine the possible effects of these relationships on students' loyalty.

The results show that quality of service is a key driver for Students' satisfaction. Among the educational services evaluated, Teaching and lectures and Teaching and course organization were revealed to be the most important. Contrary to expectations, Educational infrastructure and Libraries do not have a direct influence on satisfaction, and the contribution of Refectories is rather weak. Furthermore, the crucial role played by University image is worth noting, both for its direct and indirect effects on Students' satisfaction and Students' loyalty. In particular, students who believe they are enrolled in a prestigious, modern and famous university are likely to assess their experience more satisfactorily. This also happen through the mediation of teaching and lecture activities, and thus University image proves to be the most important factor affecting Teaching and lectures. This seems to demonstrate that the possible conditioning exercised by students' impressions and prevailing beliefs or feelings towards the institution are essential not only for assessing the university experience as more satisfying in general but also for a positive assessment of the perceived quality of teaching, that is, independent from the actual delivery. In particular, it is reasonable to believe that this kind of evaluation, based on perceptions, can provide a different concept of quality when compared to that obtained by students' opinions about courses taken and the teaching, collected through questionnaires compiled at the end of each semester. Indeed, the latter refers to specific features of teaching, such as good lecturers' presentation skills, course material, teacher-student relationship, overall satisfaction and so on, for which students may give positive or negative assessments based on actual course delivery. On the other hand, the former more probably defines a much broader concept of quality of teaching, on which intangible aspects such as sensations, impressions and individual feelings towards the university, but also communication and social values as well as history, prestige, reputation, and knowledge of celebrated alumni can play a decisive role. This last result seems particularly noteworthy and differentiates this study from previous studies which have dealt with the same issues.

As regard the relationship between Student's service offices and Student's satisfaction, the negative effect could be due to the fact that students who address to Student's service offices for assistance are more likely those who have problems during their career. As a consequence, their perceived satisfaction is lower because of their problems, although they could be satisfied with the received support service.

Finally, two possible and interesting implications may result. The first is that in an increasingly competitive environment, universities are encouraged to pay close attention to the quality of educational service in order to enhance the satisfaction and loyalty of their students. The second is the importance of institutional image in higher education settings. As a consequence, universities might decide to allocate part of their resources to communications and marketing strategies for developing a distinguishable image and market position against those of their competitors in order to gain a competitive edge.

\section{References}

Abdullah, F., (2006). Measuring service quality in higher education: three instruments compared. International Journal of Research \& Method in Education, 29(1), 71-89.

Aghaza, A., Hashemia, A., Atashgaha, M.S.S. (2015). Factors contributing to university image: the postgraduate students' points of view. Journal of Marketing for Higher Education, 25(1), 104-126.

Alves, H., Raposo, M. (2007). Conceptual model of student satisfaction in higher education. Total Quality Management \& Business Excellence, 18(5), 571-588. 
Arpan, L., Raney, A., Zivnuska, S. (2003). A cognitive approach to understanding university image. Corporate Communications: An International Journal, 8(2), 97-113.

Arslan, S., Akkas, O.A. (2014). Quality of college life (QCL) of students in Turkey: students' life satisfaction and identification. Social Indicators Research, 115(2), 869884.

Baldwin, G., James, R. (2000). The market in Australian higher education and the concept of student as informed consumer. Journal of Higher Education Policy and Management, 22(2), 139-48.

Bagozzi, R.P., Yi, Y. (1998). On the evaluation of structural equation models. Academy of Marking Science, 16(1), 76-94.

Bandalos, D.L. (2014). Relative performance of categorical diagonally weighted least squares and robust maximum likelihood estimation. Structural Equation Modeling: A Multidisciplinary Journal, 21(1), 102-116.

Bini, M., Masserini, L. (2016). Students' satisfaction and teaching efficiency of university offer. Social Indicators Research, 129(2), 847-862.

Bollen, K.A. (1989). Structural equations with latent variables. John Wiley and Sons, New York.

Brown, R.M., Mazzarol, T.W. (2009). The importance of institutional image to student satisfaction and loyalty with higher education. Higher Education, 58, 81-95.

Cronbach, L.J. (1951). Coefficient alpha and the internal structure of tests. Psychometrika, 16(3), 297-334.

Cronin, J.J., Taylor, S.A. (1992). Measuring service quality: reexamination and extension. Journal of Marketing, 56(3), 55-68.

Dana, S.W., Brown, F.W., Dodd, N.G. (2001). Student perception of teaching effectiveness: a preliminary study of the effects of professors' transformational and contingent reward leadership behaviors. Journal of Business Education, 2, 53-70.

DeBourgh, G.A. (2003). Predictors of student satisfaction in distance-delivered graduate nursing courses: what matters most? Journal of Professional Nursing, 19(3), 149-163.

DeShields, O.W., Kara, A., Kaynak, E. (2005). Determinants of business student satisfaction and retention in higher education: applying Herzberg's two-factor theory. International Journal of Educational Management, 19(2), 128-139.

Douglas, J., Douglas, A., Barnes, B. (2006). Measuring student satisfaction at a UK university. Quality Assurance in Education, 14(3), 251-267.

Duarte, P.O., Alves, H.B., Raposo, M.B. (2010). Understanding university image: a structural equation model approach. International Review on Public and Nonprofit Marketing, 7, 21-36.

Elliott, K., Healy, M. (2001). Key factors influencing student satisfaction related to recruitment and retention. Journal of Marketing for Higher Education, 10(4), 1-12.

Elliott, K.M., Shin, D. (2002). Student Satisfaction: an alternative approach to assessing this important concept. Journal of Higher Education Policy and Management, 24(2), 199209.

Eskildsen, J., Martensen, A., Gronholdt, L., Kristensen, K. (1999). Benchmarking student satisfaction in higher education based on the ECSI methodology. Proceedings of the TQM for higher education institutions conference: Higher Education Institutions and the Issue of Total Quality, Verona, (30-31 August), 385-402.

Forero, C.G., Maydeu-Olivares, A., Gallardo-Pujol, D. (2009). Factor analysis with ordinal indicators: a Monte Carlo study comparing DWLS and ULS estimation. Structural Equation Modeling: A Multidisciplinary Journal 16(4): 625-641.

Foskett, N.H., Hemsley-Brown, J.V. (2001). Choosing futures: Young people's decisionmaking in education, training and careers markets. Routledge/Falmer, London. 
Gibson, A. (2010). Measuring business student satisfaction: a review and summary of the major predictors. Journal of Higher Education Policy and Management, 32(3), 251259.

Gruber, T., Fuß, S., Voss, R., Gläser-Zikuda M. (2010). Examining student satisfaction with higher education services: using a new measurement tool. International Journal of Public Sector Management, 23(2), 105-123.

Grunwald, H., Peterson, M.W. (2003). Factors that promote faculty involvement in and satisfaction with institutional and classroom student assessment. Research in Higher Education, 44(2), 173-204.

Guolla, M. (1999). Assessing the teaching quality to student satisfaction relationship: applied customer satisfaction research in the classroom. Journal of Marketing Theory and Practice, 7(3), 87-97.

Hartman, D.E., Schmidt, S.L. (1995). Understanding student/alumni satisfaction from a consumer's perspective: the effects of institutional performance and program outcomes. Research in Higher Education, 36(2), 197-217.

Harvey, L. (1995). Student satisfaction. The New Review of Academic Librarianship, 1, 161-73.

Harvey, L. (2003). Student Feedback. Quality in Higher Education 9(1): 3-20

Harvey, L., Green, D. (1993). Defining quality. Assessment \& Evaluation in Higher Education, 18(1), 9-34.

Hashim, N.A.B., Abdullateef, A.O., Sarkindaji, B.D. (2015). The moderating influence of trust on the relationship between institutional image/reputation, perceived value on student loyalty in higher education institution. International Review of Management and Marketing, 5(3), 122-128.

Hemsley-Brown, J.V., Oplatka, I. (2006). Universities in a competitive global marketplace: a systematic review of the literature on higher education marketing. International Journal of Public Sector Management, 19(4), 316-338.

Henning-Thurau, T., Lager, M.F., Hansen, U. (2001). Modelling and managing student loyalty: an approach based on the concept of relationship quality. Journal of Service Research, 3(1), 331-344.

Hu, L., Bentler, P.M. (1999). Cutoff criteria for fit indexes in covariance structure analysis: Conventional criteria versus new alternatives. Structural Equation Modeling: A Multidisciplinary Journal, 6(1), 1-55.

Ilias, A., Hasan, H.F.A., Rahman, R.A., Yasoa, M.R. (2008). Student satisfaction and service quality: any differences in demographic factors? International Business Research, 1(4), 131-143.

Jöreskog, K.G. (1969). A general approach to confirmatory maximum likelihood factor analysis. Psychometrika, 34, 183-202.

Landrum, R., Turrisi, R., Harless, C. (1998). University image: the benefits of assessment and modeling. Journal of Marketing for Higher Education, 9(1), 53-68.

Lindsey, R.R. (2012). The benefits and satisfaction of participating in campus recreational sports facilities and programs among male and female African American students: A pilot study. Recreational Sports Journal, 36(1), 13-24.

Marzo-Navarro, M., Pedraja-Iglesias, M., Rivera-Torres, M.P. (2005). Measuring customer satisfaction in summer courses. Quality Assurance in Education, 13(1), 53-65.

Mergen, E., Grant, D., Widrick, S.M. (2000). Quality management applied to higher education. Total Quality Management, 11(3), 345-352.

Muthén, B. (1984). A general structural equation model with dichotomous ordered categorical and continuous latent variable indicators. Psychometrika 49(1): 115-132.

Muthén, B., du Toit, S.H.C., Spisic, D. (1997). Robust inference using weighted least squares and quadratic estimating equations in latent variable modeling with categorical and continuous outcomes. Unpublished manuscript. 
Muthén, L.K., Muthén, B.O. (1998-2010). Mplus user’s guide (6th ed.). Muthén \& Muthén, Los Angeles, CA.

Muthén, B., Satorra, A. (1995). Technical aspects of Muthén's LISCOMP approach to estimation of latent variable relations with a comprehensive measurement model. Psychometrika 60(4): 489-503.

Nguyen, N., LeBlanc, G. (2001). Image and reputation of higher education institutions in students' retention decisions. The International Journal of Educational Management, 15(6/7), 303-311.

Oldfield, B., Baron, S. (2000). Student perceptions of service quality in a UK university business and management faculty. Quality Assurance in Education, 8(2), 85-95.

Palacio, A., Meneses, G., Pérez, P. (2002). The configuration of the university image and its relationship with the satisfaction of students. Journal of Educational Administration, 40(5), 486-505.

Petruzzellis, L., D’Uggento, A.M., Romanazzi, S. (2006). Student satisfaction and quality of service in Italian universities. Managing Service Quality: An International Journal, 16(4), 349-364.

Poturak, M. (2014). Private universities service quality and student's satisfaction. Global Business and Economics Research Journal, 3(2), 33-49.

Pozo-Munoz, C., Rebolloso-Pacheco, E., Fernandez-Ramierz, B. (2000). The 'ideal teacher'. Implications for student evaluation of teaching effectiveness. Assessment \& Evaluation in Higher Education, 25 (3), 253-263.

Rojas-Méndez, J.I., Vasquez-Parraga, A.Z., Kara, A., Cerda-Urrutia, A. (2009). Determinations of student loyalty in higher education: a tested relationship approach in Latin America. Latin American Business Review, 10, 21-39.

Sapri, M., Kaka, A., Finch, E. (2009). Factors that influence student's level of satisfaction with regards to higher educational facilities services. Malaysian Journal of Real Estate, 4(1), 34-51.

Skrondal, A., Rabe-Hesketh, S. (2004). Generalized latent variable modeling: multilevel, longitudinal, and structural equation models. Chapman \& Hall/CRC, Boca Raton.

Sojkin, B., Bartkowiak, P., Skuza, A. (2012). Determinants of higher education choices and student satisfaction: the case of Poland. Higher Education, 63, 565-581.

Srikanthan, G., Dalrymple, J. (2003). Developing alternative perspectives for quality in higher education. International Journal of Educational Management, 17(3), 126-136.

Tarus, D.K., Rabach, N. (2013). Determinants of customer loyalty in Kenya: does corporate image play a moderating role? The TQM Journal, 25(5), 473-491.

Thomas, E., Galambos, N. (2004). What satisfies students? Mining student-opinion data with regression and decision tree analysis. Research in Higher Education, 45(3): 251269.

Umbach, P.D., Porter, S.R. (2002). How do academic departments impact student satisfaction? Understanding the contextual effects of departments. Research in Higher Education, 43(2), 209-233.

Voss, R., Gruber, T., Szmigin, I. (2007). Service quality in higher education: The role of student expectations. Journal of Business Research, 60(9), 949-959.

Webb, D., Jagun, A. (1997). Customer care, customer satisfaction, value, loyalty and complaining behavior: validation in a UK university setting. Journal of Consumer Satisfaction, Dissatisfaction and Complaining Behavior, 10, 139-51. 
Appendix

$\underline{\text { Highly qualified teachers }\left(\mathrm{y}_{1}\right)}$

\begin{tabular}{lcc}
\hline & $\mathrm{N}$ & $\%$ \\
\hline none & 6805 & 45.8 \\
little & 6408 & 43.1 \\
enough & 1026 & 6.9 \\
much & 631 & 4.2 \\
\hline Total & 14870 & 100.0 \\
\hline
\end{tabular}

Quality of the teaching activity (y2)

\begin{tabular}{lcc}
\hline & $\mathrm{N}$ & $\%$ \\
\hline none & 7773 & 52.3 \\
little & 5701 & 38.3 \\
enough & 891 & 6.0 \\
much & 505 & 3.4 \\
\hline Total & 14870 & 100.0 \\
\hline
\end{tabular}

Quality of research $\left(\mathrm{y}_{3}\right)$

\begin{tabular}{lcc}
\hline & $\mathrm{N}$ & $\%$ \\
\hline none & 5881 & 39.5 \\
little & 7058 & 47.5 \\
enough & 1046 & 7.0 \\
much & 885 & 6.0 \\
\hline Total & 14870 & 100.0 \\
\hline
\end{tabular}

Organization of exams (appeals, information, bookings) $\left(\mathrm{y}_{4}\right)$

\begin{tabular}{lcc}
\hline & $\mathrm{N}$ & $\%$ \\
\hline none & 1005 & 6.8 \\
little & 3693 & 24.8 \\
enough & 6648 & 44.7 \\
much & 3524 & 23.7 \\
\hline Total & 14870 & 100.0
\end{tabular}

Class schedule ( $\left.\mathrm{y}_{5}\right)$

\begin{tabular}{lcc}
\hline & $\mathrm{N}$ & $\%$ \\
\hline none & 964 & 6.5 \\
little & 3483 & 23.4 \\
enough & 7729 & 52.0 \\
much & 2694 & 18.1 \\
\hline Total & 14870 & 100.0 \\
\hline
\end{tabular}

Support provided by non-academic personnel (y6)

\begin{tabular}{lcc}
\hline & $\mathrm{N}$ & $\%$ \\
\hline none & 1113 & 1.5 \\
little & 3413 & 12.5 \\
enough & 7350 & 63.8 \\
much & 2995 & 22.2 \\
\hline Total & 14870 & 100.0 \\
\hline
\end{tabular}

Online services $\left(\mathrm{y}_{7}\right)$

\begin{tabular}{lcc}
\hline & $\mathrm{N}$ & $\%$ \\
\hline none & 730 & 4.9 \\
little & 3542 & 23.8 \\
enough & 6747 & 45.4 \\
much & 3851 & 25.9 \\
\hline Total & 14870 & 100.0 \\
\hline
\end{tabular}

Lecture halls (y8)

\begin{tabular}{lcc}
\hline & $\mathrm{N}$ & $\%$ \\
\hline none & 1134 & 7.6 \\
little & 4915 & 33.1 \\
enough & 7262 & 48.8 \\
much & 1559 & 10.5 \\
\hline Total & 14870 & 100.0 \\
\hline
\end{tabular}

$\underline{\left.\text { Laboratories ( } \mathrm{y}_{9}\right)}$

\begin{tabular}{lcc}
\hline & $\mathrm{N}$ & $\%$ \\
\hline none & 2816 & 18.9 \\
little & 6371 & 42.8 \\
enough & 4751 & 31.9 \\
much & 932 & 6.3 \\
\hline Total & 14870 & 100.0 \\
\hline
\end{tabular}

Cleanliness $\left(\mathrm{y}_{10}\right)$

\begin{tabular}{lcc}
\hline & $\mathrm{N}$ & $\%$ \\
\hline none & 943 & 6.3 \\
little & 4000 & 26.9 \\
enough & 7763 & 52.2 \\
much & 2164 & 14.6 \\
\hline Total & 14870 & 100.0 \\
\hline
\end{tabular}

$\underline{\text { Meeting places }\left(\mathrm{y}_{11}\right)}$

\begin{tabular}{lcc}
\hline & $\mathrm{N}$ & $\%$ \\
\hline none & 791 & 5.3 \\
little & 4805 & 32.3 \\
enough & 7646 & 51.4 \\
much & 1628 & 10.9 \\
\hline Total & 14870 & 100.0 \\
\hline
\end{tabular}

$\underline{\text { Number of seats }\left(\mathrm{y}_{12}\right)}$

\begin{tabular}{lcc}
\hline & $\mathrm{N}$ & $\%$ \\
\hline none & 1250 & 8.4 \\
little & 6318 & 42.5 \\
enough & 6573 & 44.2 \\
much & 730 & 4.9 \\
\hline Total & 14870 & 100.0 \\
\hline
\end{tabular}


Opening hours ( $\left.\mathrm{y}_{13}\right)$

\begin{tabular}{lcc}
\hline Opening hours $\left(\mathrm{y}_{13}\right)$ & $\mathrm{N}$ & $\%$ \\
\hline none & 536 & 3.6 \\
little & 2211 & 14.9 \\
enough & 8121 & 54.6 \\
much & 4002 & 26.9 \\
\hline Total & 14870 & 100.0 \\
\hline
\end{tabular}

$\underline{\text { Number and variety of journals/databases }\left(\mathrm{y}_{14}\right)}$

\begin{tabular}{lcc}
\hline & $\mathrm{N}$ & $\%$ \\
\hline none & 347 & 2.3 \\
little & 3459 & 23.3 \\
enough & 9705 & 65.3 \\
much & 1359 & 9.1 \\
\hline Total & 14870 & 100.0 \\
\hline
\end{tabular}

Availability of textbooks ( $\left.\mathrm{y}_{15}\right)$

\begin{tabular}{lcc}
\hline & $\mathrm{N}$ & $\%$ \\
\hline none & 250 & 1.7 \\
little & 2001 & 13.5 \\
enough & 9297 & 62.5 \\
much & 3322 & 22.3 \\
\hline Total & 14870 & 100.0
\end{tabular}

Quality of food ( $\left.\mathrm{y}_{16}\right)$

\begin{tabular}{lcc}
\hline & $\mathrm{N}$ & $\%$ \\
\hline none & 627 & 4.2 \\
little & 3987 & 26.8 \\
enough & 8869 & 59.6 \\
much & 1387 & 9.3 \\
\hline Total & 14870 & 100.0 \\
\hline
\end{tabular}

$\underline{\text { Variety of menu }\left(\mathrm{y}_{17}\right)}$

\begin{tabular}{lcc}
\hline & $\mathrm{N}$ & $\%$ \\
\hline none & 443 & 3.0 \\
little & 3679 & 24.7 \\
enough & 8518 & 57.3 \\
much & 2230 & 15.0 \\
\hline Total & 14870 & 100.0 \\
\hline
\end{tabular}

Cleaning (y18)

\begin{tabular}{lcc}
\hline Cleaning $(\mathrm{y} 18)$ & $\mathrm{N}$ & $\%$ \\
\hline none & 127 & 0.9 \\
little & 1162 & 7.8 \\
enough & 9891 & 66.5 \\
much & 3690 & 24.8 \\
\hline Total & 14870 & 100.0 \\
\hline
\end{tabular}

Information on administrative procedures and practices (y19)

\begin{tabular}{lcc}
\hline & $\mathrm{N}$ & $\%$ \\
\hline none & 390 & 2.6 \\
little & 3093 & 20.8 \\
enough & 8667 & 58.3 \\
much & 2721 & 18.3 \\
\hline Total & 14870 & 100.0 \\
\hline
\end{tabular}

$\underline{\text { Online services }\left(\mathrm{y}_{20}\right)}$

\begin{tabular}{|c|c|c|}
\hline & $\mathrm{N}$ & $\%$ \\
\hline none & 168 & 1.1 \\
\hline little & 1328 & 8.9 \\
\hline enough & 7578 & 51.0 \\
\hline much & 5796 & 39.0 \\
\hline Total & 14870 & 100.0 \\
\hline
\end{tabular}

Response times to email requests ( $\left.\mathrm{y}_{21}\right)$

\begin{tabular}{lcc}
\hline & $\mathrm{N}$ & $\%$ \\
\hline none & 759 & 5.1 \\
little & 2868 & 19.3 \\
enough & 7476 & 50.3 \\
much & 3767 & 25.3 \\
\hline Total & 14870 & 100.0 \\
\hline
\end{tabular}

Relationship with the staff ( $\left.\mathrm{y}_{22}\right)$

\begin{tabular}{lcc}
\hline & $\mathrm{N}$ & $\%$ \\
\hline none & 763 & 5.1 \\
little & 3317 & 22.3 \\
enough & 8141 & 54.7 \\
much & 2649 & 17.8 \\
\hline Total & 14870 & 100.0 \\
\hline
\end{tabular}

\begin{tabular}{lcc}
\multicolumn{2}{c}{ Support provided by staff $\left(\mathrm{y}_{23}\right)$} & \\
\hline none & $\mathrm{N}$ & $\%$ \\
little & 1300 & 8.7 \\
enough & 4032 & 27.1 \\
much & 6835 & 46.0 \\
\hline Total & 2703 & 18.2 \\
\hline
\end{tabular}

\begin{tabular}{lcc}
\multicolumn{1}{c}{ Prestigious (y24) } & & \\
\hline & $\mathrm{N}$ & $\%$ \\
\hline none & 9372 & 63.0 \\
little & 4840 & 32.5 \\
enough & 403 & 2.7 \\
much & 255 & 1.7 \\
\hline Total & 14870 & 100.0 \\
\hline
\end{tabular}


Modern ( $\left.\mathrm{y}_{25}\right)$

\begin{tabular}{lcc}
\hline & $\mathrm{N}$ & $\%$ \\
\hline none & 3707 & 24.9 \\
little & 8006 & 53.8 \\
enough & 1942 & 13.1 \\
much & 1215 & 8.2 \\
\hline Total & 14870 & 100.0
\end{tabular}

Famous (y26)

\begin{tabular}{lcc}
\hline & $\mathrm{N}$ & $\%$ \\
\hline none & 11455 & 77.0 \\
little & 2291 & 15.4 \\
enough & 376 & 2.5 \\
much & 749 & 5.0 \\
\hline Total & 14870 & 100.0 \\
\hline
\end{tabular}

In contact with the labour market (y27)

\begin{tabular}{lcc}
\hline & $\mathrm{N}$ & $\%$ \\
\hline none & 2798 & 18.8 \\
little & 7190 & 48.4 \\
enough & 2023 & 13.6 \\
much & 2859 & 19.2 \\
\hline Total & 14870 & 100.0 \\
\hline
\end{tabular}

Satisfaction with the choice of enrolling at the

University of Pisa (y28)

\begin{tabular}{lcc}
\hline & $\mathrm{N}$ & $\%$ \\
\hline none & 277 & 1.9 \\
little & 1476 & 9.9 \\
enough & 7994 & 53.8 \\
much & 5123 & 34.4 \\
\hline Total & 14870 & 100.0
\end{tabular}

Satisfaction compared to initial expectations ( $\left.\mathrm{y}_{29}\right)$

\begin{tabular}{lcc}
\hline & $\mathrm{N}$ & $\%$ \\
\hline none & 748 & 5.0 \\
little & 3261 & 21.9 \\
enough & 7917 & 53.2 \\
much & 2944 & 19.8 \\
\hline Total & 14870 & 100.0
\end{tabular}

Overall satisfaction $\left(\mathrm{y}_{30}\right)$

\begin{tabular}{lcc}
\hline & $\mathrm{N}$ & $\%$ \\
\hline none & 225 & 1.5 \\
little & 1861 & 12.5 \\
enough & 9488 & 63.8 \\
much & 3297 & 22.2 \\
\hline Total & 14870 & 100.0
\end{tabular}

$\underline{\left.\text { Intention to enrol again at the University of Pisa ( } \mathrm{y}_{31}\right)}$

\begin{tabular}{lcc}
\hline & $\mathrm{N}$ & $\%$ \\
\hline yes & 1989 & 13.4 \\
not & 12881 & 86.6 \\
\hline Total & 14870 & 100.0
\end{tabular}

Intention to recommend the University of Pisa to a

relative, a friend or an acquaintance ( $\left.\mathrm{y}_{32}\right)$

\begin{tabular}{lcc}
\hline & $\mathrm{N}$ & $\%$ \\
\hline yes & 1695 & 11.4 \\
not & 13175 & 88.6 \\
\hline Total & 14870 & 100.0 \\
\hline
\end{tabular}

